\title{
DEVOLUTION, THE BRITISH CONSTITUTION AND THE DISTRIBUTION OF POWER
}

\author{
Peter Leyland, School of Law, Governance and International \\ Relations, London Metropolitan University
}

\section{INTRODUCTION}

This article provides a critical discussion of important aspects of the UK devolution arrangements which came into effect in 1999. There will only be brief mention of the main characteristics, as the principal concern is not to map the functions that have been devolved, but to focus on the immediate implications of the arrangements. The first sections consider some of the most obvious deficiencies in the legislation in relation to the way power has been distributed, especially in regard to funding arrangements, sovereignty and political representation, while the remainder of the discussion attempts to consider devolution in a broader context, namely, in terms of the manner in which power is exercised more widely in the modern state. The objective here is to concentrate on some of the questions of governance that arise beneath the surface of the main institutional provisions. Four areas have been selected for discussion: concordats, compacts, regulation and deregulation, and the EU representation of the UK post devolution.

The current devolution arrangements are both a realisation of long held aspirations of advocates of devolved government in Scotland, Wales and Northern Ireland and a political reaction to the centralising tendencies of government that were particularly noticeable during the 1980's and 1990's. For the most part UK devolution, which has been on and off the political agenda for the last thirty years, can be viewed as a settlement (for the time being at least) which has been "made to measure" for each of the nations. Nevertheless, rough parallels have frequently been drawn with Spain which likewise has nationalism confined to particular geographical regions and has therefore taken an asymmetrical approach to redistributing power. ${ }^{1}$ On the other hand, the UK legislation, even in the case of Scotland, stops significantly short of introducing anything approaching a federal system on the German model. There are certain affinities with the European Union principle of subsidiarity which was incorporated as a check to any centralising initiatives resulting in a European super state. ${ }^{2}$ However, viewed from a wider European context, these changes do not appear to be directly connected to other emerging demands for local self determination. For example the resurgence of the many local national movements that were

$\square$ I would like to thank Rick Rawlings, Brigid Hadfield, Terry Woods and Brian Tutt for their very helpful comments on earlier drafts of this article.

1 See e.g. J. Hopkins Devolution in Context: Regional, Federal and Devolved Government in the European Union, (2002) at p 46 and p 120ff; R. Hazell and B. O'Leary 'A Rolling Programme of Devolution: Slippery Slope or Safeguard of the Union' in R. Hazell Constitutional Futures: A History of the Next Ten Years, (1999) at pp 24-27.

2 See P. Craig and G. De Burca EU Law: Text, Cases and Materials, $2^{\text {nd }}$ ed (1998) at p 124ff. 
given impetus by the demise of the former Soviet Union and the collapse of Yugoslavia. ${ }^{3}$

For the purposes of this analysis there will be emphasis on the contrast between the apparent exercise of political power and the impact of devolution on the wider process of policy making and administration. Clearly, the devolution measures were a pragmatic response by a pragmatic government and it turns out to be not one but a series of plays. Each one carefully plotted to include a set of reforms which have been calculated at a political level to placate dissatisfaction with the ever more centralising tendencies of the state. But some would argue that it goes beyond what even its architects envisaged. It has been suggested that the legislation is so comprehensive in its provisions, especially those dealing with the electoral system and the functions of Parliament/Assembly, that each statute can be regarded as equivalent to a constitution for its respective part of the UK. ${ }^{4}$

On the other hand, it could be argued that devolution merely sets a democratic seal on a governmental and administrative formation that had already been largely set in place. For instance, this is particularly true in regard to Scotland which has never been wholly incorporated into the UK and always retained its own distinctive church, legal and educational system $^{5}$. To allow for this, Westminster legislation intended for Scotland (and also Wales) followed a different procedure. ${ }^{6}$ But also at the level of policy implementation the growth of executive devolution was a feature of the system of government of the twentieth century. ${ }^{7}$ Power in many policy fields had come to be exercised by officials under the direction of a Secretary of State for Scotland, Wales or Northern Ireland. In the light of the executive changes alluded to, it might be observed that the powers that have been devolved are predictable. For the most part in Scotland and Wales these powers correspond to the remit and responsibilities of the previous departments of state. Thus there has been a history of the accretion of powers to the Scottish and Welsh Offices with the growth of the administrative state and that these powers now rest with the newly formed executives. While in the case of Northern Ireland it was the devolved powers that had been vested in the Stormont system of government that reverted to the Northern Ireland Office following the collapse of the system in $1972 .{ }^{8}$

3 See e.g. E. Hobsbawm Age of Extremes: The Short Twentieth Century 1914-1991, (1994) chapter 16 'End of Socialism'.

4 AJ Ward 'Devolution: Labour's Strange Constitutional Design', in Jowell J \& Oliver D The Changing Constitution, (2000) at p 112.

5 See e.g. the Treaty of Union 1707 Articles 18 guaranteed Scottish private law. Scottish Act of Security 1706 secured the protestant religion and the Presbyterian Church.

6 The role of the Scottish/Welsh Grand Committee. See A Bradley \& K Ewing Constitutional and Administrative Law, 12 $2^{\text {th }}$ ed (1997) at $\mathrm{p} 201$.

7 Enforced compliance with central government policy was possible even where the local electorate opposed the policy. See D. Griffiths 'The Welsh Office and Welsh Autonomy' [1999] Public Administration 793-807 at p 805; I. Holliday 'Scottish Limits to Thatcherism' 1992, Political Quarterly 448-459.

8 V. Bogdanor Devolution in the United Kingdom, (1999), at p 99. 
One notable feature of the hand over of power since devolution has been a smooth transition with little or no disruption to the delivery of policy. ${ }^{9}$ In an important sense the significance of devolution is that by establishing elected assemblies with powers of scrutiny through new subject committees, it supplies greatly improved mechanisms of accountability that involve an increased political participation. ${ }^{10}$ Indeed, a further effect of conferring power locally has been to throw open the question of regional government for England which in terms of political representation is now treated less favourably to Scotland, Wales and Northern Ireland. ${ }^{11}$ Finally, it should also be recognised that in constitutional terms devolution has a special kind of status. Although the doctrine of sovereignty prevents any entrenchment in the same sense as there is in the USA or other written constitutions the device of the referendum as a democratic seal of approval (e.g. as with the EU) - would make the dismantling of these arrangements much more difficult than with other legislation. ${ }^{12}$

So, in summary, devolution provides a new level of government subordinate to Westminster on an asymmetrical basis. It establishes a democratically elected Scottish Parliament with the power to pass primary legislation. It sets up power sharing arrangements in Northern Ireland, also based on a different PR system of elections with the power to pass primary legislation and an elected Welsh Assembly with no power to pass primary legislation. ${ }^{13}$ Moreover, the mechanisms of accountability that have been set in place as part of devolution are in many ways superior to those at Westminster. The Labour party claimed that it would bring democracy closer to the people by introducing these reforms. Devolution not only provides the electorate in each nation with the right to vote on the basis of proportional representation but each piece of legislation successfully introduces democratic institutions and processes.

\section{(1) The Democratic Politics of Devolution}

We shall see that the view that there has been a substantial shift of power can be supported, in part at least, by some of the evidence of the political

9 This was possible through a series of concordats drawn up between Whitehall and the new executives e.g. Concordat between the Cabinet Office and the Scottish Administration. The significance of concordats is discussed in greater detail below.

10 In Northern Ireland this is achieved by a system of power sharing at every level. An impressive feature in Scotland is the proportion of women in the Scottish Parliament (37\% SMPs).

11 For example, the West Lothian question discussed later. According to many experts England does relatively badly out of the Barnett formula. See note 24 below. The introduction of an elected Mayor and Assembly for London is closely related to these measures and might also be viewed as part of a commitment to redress a perceived 'democratic deficit'. See Greater London Authority Act 1999.

12 M. Loughlin Sword \& Scales: An Examination between Law and Politics, (2000) notes at p 154, "And although the Scotland Act 1998 takes the form of a devolution of legislative authority to a subordinate body, it is inconceivable that the courts would rule that powers conferred on the Scottish Parliament cannot lawfully be withdrawn without the consent of that institution?'

13 For an in depth contextual discussion of Welsh Devolution see R. Rawlings 'The New Model Wales' Journal of Law and Society, 1998 461-509. Section IV 'Lawmaking and Adjudication' deals with the functions of the assembly. 
tensions that have emerged following the activation of the legislation. ${ }^{14}$ For example, it is already very evident that a new political force has been unleashed by the devolution process. It may even be suggested that it is the case of the tail wagging the dog with Scotland forcing the pace in regard to English policy on student grants, free personal care for the elderly, freedom of information and producing a more streamlined industrial culture. The introduction of coalition government, with each party having to respond to local demands already indicates that national political parties are ceasing to be monolithic institutions that can be readily controlled from the centre ${ }^{15}$. In some areas policies have been pursued by a Labour dominated administration in Scotland and Wales which conflict with the policy of the Westminster government. This tendency has the potential to influence national policy making. For example, take the decision by the Labour government to introduce tuition fees for university students which faced more intense opposition in Scotland. ${ }^{16}$ Education is an area that falls under the responsibility of the Scottish Parliament and the imposition of student tuition fees and loans was an important issue at the Scottish general election held in May 1999. The Scottish Nationalists and Liberal Democrats in Scotland declared support for the restoration of a subsistence allowance for poorer students in Scotland. As part of the post-election coalition deal between the Labour and the Liberal Democrats the Cubie Committee was set up to look into this matter. Following the publication of the committee's report $^{17}$ the Labour and Liberal Democrat coalition agreed to partly abolish tuition fees for Scottish students and replace them with a tuition endowment. ${ }^{18}$ Since students from England, Scotland, Wales and Northern Ireland can choose to be educated at universities anywhere in the UK, this means that the arrangements for students in Scotland call into question the Westminster government's system of means tested tuition fees and means tested loans, as this results in Scottish students being treated more favourably than other students.

Also, the national Labour party based in London has failed to successfully exert pressure on its Scottish counterpart to fall into line on this question. Indeed, the changes to student fees and funding in Scotland may have an impact on the policy that is adopted in this area by the government in England and Wales. But more generally it would seem likely that disputes of this kind will tend to fragment the existing party system. Ultimate accountability to a different electorate will result in the gradual abandonment

14 For a summary of the initial political impact of devolution see E. Bort 'Devolution and the end of Britain' Politics Review, February 2001, pp 28-30.

15 M. Laffin, A. Thomas and A. Webb 'Intergovernmental Relations after Devolution: The National Assembly for Wales' Political Quarterly [2000] pp 223233 at $\mathrm{p} 225$. The replacement of Alun Michael by Rhodri Morgan in February 2000 illustrates the emerging tension between Cardiff and London. The last straw that prompted Michael's resignation was his inability as first minister to secure additional EU funding for Wales.

16 See Education Act 1997.

17 The Independent Committee of Inquiry into Student Finance; $\mathrm{http} / / / \mathrm{www}$.studentfinance.org.uk /final/

18 See e.g. The Sunday Herald $16^{\text {th }}$ January 2000. 
of old party loyalties. ${ }^{19}$ In one sense this might be regarded as a vindication of devolution - it supports the case that having an elected Parliament/Assembly with divergent views can lead to a real choice of policy, tailored to meet local demands expressed through a more democratic process.

This has not been a one-way process. To stem the tide of dissent and reassert power from the centre the Labour party hierarchy have striven to quite blatantly manipulate the selection process of candidates. ${ }^{20}$ This has been to secure the leadership's preferred choice for the most prestigious posts of Scottish First Minister, Welsh First Secretary and London Mayor. However, the attempts to keep a tight reign have not been very successful. ${ }^{21}$ Rhodri Morgan succeeded Alun Michael as Welsh Secretary after a no confidence vote in the Welsh Assembly confirmed the lack of support for his leadership and Ken Livingstone (though excluded from the party) was elected as London Mayor on an independent ticket. ${ }^{22}$ The Scottish Conservative party is also showing signs of branding itself distinctively from its English counterpart. The combination of having to appeal to a distinctive electorate and the use of proportional representation has changed the complexion of existing political parties at the local level, fragmenting the existing system. And given more time this may also encourage the formation of new political parties. ${ }^{23}$

\section{(2) Constitutional Limitations}

Devolution is significant because it has led to a formal division and delegation of aspects of the political process and it marks a major departure in that the UK is arguably no longer a unitary state. However, viewed from the standpoint of constitutional design, the devolution legislation has a number of obvious weaknesses. For instance, these are not only that both the purse strings and sovereignty remain in the hands of Westminster but the new arrangements fail to address the issue of inequality of representation in the Westminster Parliament.

\section{(i) The Funding of Devolution}

The most obvious way in which devolution might be regarded as illusory as a meaningful conferment of power and again in which the arrangements stop well short of federalism is that the economic parameters have been largely untouched by the arrangements. ${ }^{24}$ For the Labour government a prime

19 Political difficulties for Labour also arose in Wales with the forced resignation of the Welsh First Secretary on $10^{\text {th }}$ February 2000.

20 See L. Baston 'The Party System' in A. Seldon (ed.) The Blair Effect: The Blair Government 1997-2001, (2001) pp 162-167.

21 Dennis Canavan, former MP for Falkirk West, was not selected on the basis of his left wing credentials but proceeded to win a seat for the Scottish Parliament as an independent candidate.

22 Ken Livingstone was elected Mayor in May 2000.

23 See The Guardian Editorial 15 ${ }^{\text {th }}$ December 1999 which comments on the effectiveness of the opposition parties in Scotland and the increasing independence of the political newcomers in the Scottish Parliament.

24 For a detailed discussion of the background to these funding arrangements see V. Bogdanor 1999 op cit $\mathrm{n} 8$ above $\mathrm{p} 235 \mathrm{ff}$. This question is also addressed in some 
advantage of their preferred solution in each of its manifestations (this also includes London) is that it provides a revised framework for democratic involvement and direct accountability to elected institutions but it does so with only marginal changes to resource allocation. Crucially, the Barnett formula which determines the overall budget for each part of the UK remains untouched. Of course - within the relevant areas of competency for each executive the devolution arrangements allow the budgetary amounts allocated to the respective areas of policy to be determined at a local level. But only Scotland and the London Mayor are granted any revenue raising power and this is strictly limited to a small fraction in terms of the overall budget. ${ }^{25}$ The Scottish provision is also regarded as a potential electoral suicide note for any party standing on a ticket of higher taxation. (The burgeoning costs of the new Holyrood Parliament building which have spiralled to an estimated $£ 280$ million are already regarded as a liability with the Scottish electorate). The devolution arrangements rest on questionable foundations by having democratically elected institutions with responsibility for spending but not for the raising of revenue. Westminster remains in a position where, after a process of consultation, it can vary the allocations of funding. ${ }^{26}$

\section{(ii) Sovereignty and law making powers}

Although there is no doubt that in constitutional terms the devolution legislation has a special status, the supreme law making capacity of Westminster remains intact. ${ }^{27}$ Formal limits and restraints on the devolved institutions are contained in the legislation. The sovereignty of the UK Parliament is deliberately preserved. ${ }^{28}$ This is particularly significant in relation to Scotland and Northern Ireland because the Scottish Parliament and the Northern Ireland Assembly are granted the most extensive powers to pass a form of primary legislation. ${ }^{29}$ For example, in Scotland there are procedures in place to guarantee conformity with the Scotland Act. Preenactment scrutiny requires the Scottish Minister and the Presiding Officer to confirm that in their view the bill falls within the Parliament's legislative

depth in New Economy 2000 No 7 Vol 2 64-86. See J. McConnell 'Funding Devolution: Why Barnett Remains Better than the Alternative' J. Barnett (Lord)

'The Barnett Formula: How a temporary expedient became Permanent'; Midwinter A 'The Barnett Formula: Why replacing it would be a mistake' I. McLean 'Getting and spending: can (or should the Barnett Formula Survive?'. See also R. Wilson 'Private Partners and Public Good' in this issue of the NILQ at p 454 for discussion of aspects of funding implications for Northern Ireland.

25 See Scotland Act 1998 Part IV ss 73-80.

26 A. Midwinter 'The New Accountability? Devolution and Expenditure Politics in Scotland' Public Money \& Management, July September 2001 p 47.

27 Scotland Act 1998 Section 28(7).

28 See Scotland Act 1998 Section 29 (1) which states that 'An Act of the Scottish Parliament is not law so far as any provision of the Act is outside the legislative competence of the Scottish Parliament'. Schedule 5 (about 16 pages of reserved matters).

29 See B. Winetrobe 'Scottish devolved legislation and the courts' [2002] Public Law 31-39 at p 32 where it is pointed out that although subsidiary in UK terms the legislative power can be regarded as primary when falling within the scope of the Parliament's competence. 
competence. $^{30}$ Following the passage of the bill, but prior to the Royal Assent there is a pause to allow Law Officers in London or Edinburgh to, if necessary, obtain a judicial decision on vires from the Judicial Committee of the Privy Council. The Secretary of State for Scotland is also empowered to prevent the Presiding Officer from submitting the bill for the Royal Assent by presenting reasons why a measure might conflict with international obligations, national security or matters reserved under the Act. ${ }^{31}$ In regard to Wales which has an Assembly without primary law making powers the device of a transfer order has been used to transfer the former functions of the Secretary of State for Wales contained in numerous statutes to the Assembly.

Nevertheless, it was predicted that following devolution the supremacy of Parliament would have a "different and attenuated" meaning so that "instead of enjoying a regular and continuous exercise of supremacy, [Westminster] will possess merely a nebulous right of supervision . . .". ${ }^{32}$ The point being that post devolution Westminster would find it difficult to legislate against the wishes of the Scottish Parliament or the Northern Ireland Assembly. Moreover, there was an expectation that a convention would be established whereby the UK Parliament would not normally legislate over devolved matters and that this would be an unusual occurrence which would take place with the agreement of the devolved legislature. ${ }^{33}$ However, a detailed review of the legislative record reveals that in fact Westminster legislation applying to Scotland has abounded since $1999 .{ }^{34}$ This has been to a much greater extent than anticipated. To some degree this can be accounted for by the fact that the same party is in power in Westminster with a commitment to common policy objectives. Further, there is a need to comply with international obligations on a nationwide basis ${ }^{35}$ and for participation in particular UK wide initiatives. ${ }^{36}$ Also, in certain areas there may be an advantage to having common regulatory measures. ${ }^{37}$ Page and Batey suggest that there are straightforward practical reasons for the continuing dominance of UK departments in promoting legislation across borders. For example,

30 Under the Scotland Act 1998 the Presiding Officer is elected by the MSPs (with two deputies) to perform a number of parliamentary functions, some of which are similar to those of the Speaker of the House of Commons.

31 See Scotland Act 1998 s 35; R. Rawlings 'The Shock of the New: Devolution in the United Kingdom' in E. Riedel (ed.) Aufgabenverteilung and Finanzregimes in Verhältnis zwischen dem Zentralstaat and seinem Untereinheiten, (2001) 65-93 at p 78.

32 V. Bogdanor, 1999 n 8 above at p 291.

33 This is referred to as the Sewell Convention. It acknowledges that three types of legislation require the consent of the Scottish Parliament to be proceeded with: Westminster legislation for devolved purposes; Westminster legislation altering legislative competence; and Westminster legislation altering executive competence.

34 See generally A. Page and A. Batey 'Scotland's Other Parliament: Westminster Legislation about Devolved Matters in Scotland since Devolution' 2002, Public Law 501-524.

35 The Political Parties, Elections and Referendums Act 2000. See Page and Batey 2002 op cit $\mathrm{p} 511$.

36 Food Standards Act. See Page and Batey above at n 34 p 511.

37 Regulation of Investigatory Powers Act and the Financial Services and Markets Act. Page and Batey above at p 512. 
seeing legislation enacted on a UK basis prevents unacceptable delay in the introduction of measures likely to be popular with the electorate in Scotland while leaving more time for the Scottish executive to pursue its own agenda of reform. It is also clear that legislation from the Westminster Parliament is less susceptible to challenges in the courts. ${ }^{38}$ Nonetheless, this evidence suggests that the Scottish Parliament and Scottish executive have assumed a much less prominent legislative role than seemed likely given the powers granted under the Scotland Act. It also confirms that there is a continuing pull to uniformity in the devolved system of government. ${ }^{39}$

\section{(iii) Inequality of political representation}

The so-called West Lothian question has long been recognised and it will simply be referred to here as a substantial defect in the arrangements. In essence it has been argued that establishing a powerful Scottish Parliament plays havoc with the notion of representative government in the United Kingdom. MPs representing English, Welsh and Northern Irish constituencies no longer vote on devolved matters in Scotland but Scottish MPs at Westminster retain the right to vote on domestic policy for the rest of the UK. Further still, by the transfer of many domestic functions to the Scottish Parliament Scottish Westminster MPs have a greatly reduced role to play in relation to their constituents. The obvious line of accountability for the devolved areas of domestic affairs is through their Scottish representatives. ${ }^{40}$ Of course the other related question is the lack of any equivalent level of representation for England. This is an emerging issue which has not been adequately addressed. ${ }^{41}$ Labour went into the 2001 election arguing that "there is no case for threatening the unity of the UK with an English Parliament or the denial of voting rights to Scottish, Welsh and Northern Ireland's MPs at Westminster". At the Westminster election Labour maintained its support in Scotland and Wales and so could have a great deal to lose from any further re-distribution of seats that might arise from the creation of an English Parliament.

It would seem that economic development has been the driving force behind Labour's English regional policy. ${ }^{42}$ For example, an extra tier of government opens up the opportunity of attracting more of the European Unions structural funds designated for the regions. ${ }^{43}$ Recently, the government has published proposals for English regional government which build on the existing structures, in particular the Regional Development Agencies. The proposals will allow a referendum to be held in the 9 existing English regions

38 Page and Batey 2002 above at n 34 pp 514-517.

39 Ibid p 502.

40 The significance of Westminster legislation over devolved matters requires Westminster's Scottish MP's to continue to be the guardians of Scottish interests. See A. Page and A. Batey 'Scotland's Other Parliament: Westminster Legislation about Devolved Matters in Scotland since Devolution' 2002, Public Law 501-524 at $\mathrm{p} 522$.

41 The Regional Development Act 1998 introduces a new policy for economic regeneration by dividing England into 9 regions.

42 See for example, Ambitions for Britain, Labour Party Manifesto, 2001, pp 34-35.

43 M. O'Neill 'Great Britain: From Dicey to Devolution' Parliamentary Affairs, 2000 69-96 at p 91. 
to test public support. A vote in favour will result in an assembly elected by proportional representation which will consist of between 25 and 30 members. ${ }^{44}$ The newly formed regional assemblies are not intended to add an extra tier of government or introduce any additional bureaucracy. In particular, they will not duplicate the work of either the UK Parliament or existing local authorities. In the first place, this is because the majority of functions will come from existing central government bodies and thus this is presented as representing a significant decentralisation of power. Secondly, this is because before a referendum is held on the desirability of a Regional Assembly a review will take place to ascertain the best method for a unitary structure of local government for that region. In sum, this is an attempt to improve policy delivery by extending democratic accountability and ensuring better co-ordinated government at a regional level. ${ }^{45}$ From one perspective it would appear that the White Paper proposes to put in place a system which seeks to compensate the English regions for some of the potentially adverse economic effects of devolution. However, the powers of the proposed assemblies appear modest in comparison with those given to the devolved institutions in Scotland, Wales and Northern Ireland. Moreover, the fact that any actual change is contingent on a number of regional as opposed to one national referendum is likely to lead to an even more asymmetrical distribution of competences.

\section{(3) Devolution and the Limits of Power}

The many positive features of devolution are not to be underestimated. We have seen that these changes introduce a new level of government which is more politically accountable in certain ways than Westminster. The aspirations of a substantial proportion of the local electorate have been satisfied and in the case of Wales possibly exceeded. ${ }^{46}$ Nevertheless, the question remains as to whether measures of this kind can provide an effective system of government for the devolved parts of the UK and for England. It appears that there are important arguments to consider around the potential of constitutional reform and also the potential of administrative changes of the sort alluded to. To put it simply the question might be stated thus: are constitutional modifications at the level of the nation state capable of coping with the kind of problems that are now presenting themselves at a national and sub-national level. It is not so much whether appropriate powers have been devolved, or indeed whether sufficient power has been devolved, but whether such arrangements are likely to make the delivery of policy worse rather than better, given the complexity of the mechanisms for implementation in the contemporary state.

44 See Your Region, Your Choice: Revitalising the English Regions, 2002, Cm 5511.

45 The assembly will be given control over areas such as: economic development, housing, health improvement and culture which are currently under county councils and district councils. Social services, education and other local services will remain with existing local authorities.

46 See J. Barry Jones 'The First Welsh National Assembly Elections' 1999, Government and Opposition 323-332 at p 326 who states 'Before the referendum, in September 1997, devolution was an abstract idea of little relevance for ordinary voters, more concerned with real issues that vague notions of constitutional reform'. 
At one level it can be argued that the ideas associated with the functionalist approach to public law and administration remain important as a means of assessing the measures under consideration. ${ }^{47}$ Such a view regards law as a sophisticated form of political discourse and considers not only legal decisions but laws themselves as an expression of political will. This might appear to be relevant in regard to the political considerations lying behind devolution which have already been touched upon in this article, but functionalism further rests on a belief that the state has a pro-active role in providing social welfare out of general taxation and holds that public law has a special importance because it becomes the medium which determines the delivery of certain types of universal goods such as health, education, pensions, housing and so on. It does this by providing a framework of legislation which serves as the mechanism for implementation of policy. ${ }^{48}$ In a somewhat different sense and one particularly apposite to the discussion on regulation and deregulation that follows, law also has a crucial function in protecting the general public interest by providing a layer of regulation across both the public and private sector. ${ }^{49}$ By doing this, it stands between the individual and the unmitigated effects of market forces. The potential of law in facilitating the efficient and equitable delivery of public services is recognised and encouraged by functionalists while the routine intervention of the courts into the administrative process is strongly resisted. Indeed, the objective from this standpoint is instrumental and pragmatic. It is to enhance rather than diminish the potential for good administration by designing intra vires mechanisms to achieve efficient operation of services which are at the same time democratically accountable. ${ }^{50}$ Further still, there is an assumption that universal access to benefits and services is at least as important as promoting individual rights under the ECHR or for that matter rights to national self determination. The key is to ". . . address the issues of social power at national and trans-national level which increasingly mark out the subordination of individuals". 51

47 See e.g. C. Harlow 'Changing the Mindset: The Place of Theory in English Administrative Law' 1994 OJLS 419-434 at p 424 who refers to the functionalist method which seeks to identify the goals of particular administrative systems and evaluate performance within the framework of these objectives. It is described by Cohen as questioning 'the effectiveness of various possible legal rules and arrangements'.

48 M. Loughlin Public Law and Political Theory, Oxford, OUP, 1992 see e.g., p 168ff. In his more recent work Sword \& Scales: An Examination between Law and Politics, Hart, 2000 Loughlin pursues this theme further.

49 Allison JWF A Continental Distinction in the Common Law, 1999 provides a comparative historical account and which shows how (at $p$ 87) 'The emerging theory of the state and its administration affected the justification of public law and the application of the distinction between public and private law'. He proceeds to note that Laski distrusted legal controls and emphasised parliamentary controls and citizen participation. Of course, since the 1980's the distinction between public and private law has become blurred in many areas.

50 C. Harlow and R. Rawlings Law and Administration, $2^{\text {nd }}$ ed, (1997), see e.g. pp 75-78. It has already noted there are important ways in which devolution provides enhanced mechanisms of accountability for the policy areas which fall under its remit.

51 Lord Wedderburn 'Laski's Law Behind the Law. 1906 to European Labour Law' in R. Rawlings ed Law Society and Economy, (1997) at p 61. 
However, the concern here is not so much to review the political terms of the devolution legislation, but rather to assess how these arrangements measure up as a response to the conditions of modern governance. This requires some attention to be devoted to the importance of the structural problems caused by a "hollowing out" of the state which has been subject to a loss of functions upwards to the European Union (there will be discussion of relations between the devolved governments and Europe below) and downwards towards many different bodies including agencies and the private sector $^{52}$. To add to this already complex trend,

"The devolution settlement has brought about a multi-layered government in the sense of creating different tiers or levels of government, but it has also compounded the trends towards a multi-textured democracy in which power is located in several levels of government at the same time. There is the possibility throughout the devolution settlement that power might simultaneously reside in one site of power or in multiple sites". ${ }^{53}$

Thus it can be proposed that "transformations of public administration have made more transparent the dense networks of accountability within which power is exercised". ${ }^{54}$ Indeed, given this tendency it has been persuasively argued by a number of commentators that too much faith has been placed in an "old constitutionalism" based upon reviving the role of Parliaments. Such ideas can be questioned as too closely wedded to a "liberal, individualist version of democracy".55 At the same time exposing the inadequacy of institutionalised liberal models which attempt to "guarantee an essentially non-political common good by the satisfaction of private preferences". ${ }^{56}$

It is suggested that while constitutional solutions can address certain questions reasonably effectively, there is a micro-political arena at which they fail to adequately engage. If we first take a conventional view of a constitution, it would appear that apart from setting out the rights and duties of citizens and providing the ground rules for the organisation of government, this is seen as the mechanism for laws to be rationalised in terms of legal subjectivity. It is the constitution which describes a set of institutions which will resolve the contradiction between the need for coercive political action and the equally important need to guarantee personal freedom. In practice, we see that as part of the political process programmes will be introduced in Parliament to obtain certain given policy objectives, which may then be legitimated. Assuming legitimation is

52 J. Morison 'The Case Against Constitutional Reform' [1998] Journal of Law and Society pp 510-535 at p 517. See also: Morison J \& Livingstone S Reshaping Public Power (1995). These ideas are further developed in J. Morison 'The Government-Voluntary Sector Compacts: Governance, Governmentality, and Civil Society' [2000] Journal of Law and Society, Vol 27, No 1 pp 98-132; and J. Morison 'Democracy, Governance and Governmentality: Civic Public Space and Constitutional Renewal in Northern Ireland' $O J L S$, Vol 21, No 2 (2001), 287-310.

53 N. Burrows Devolution, (2000), p 116.

54 See C. Scott 'Accountability in the Regulatory State' Journal of Law and Society [2000] p 38 at p 40.

55 Morison, 1998 n 52 above p 525.

56 Habermas quoted in Morison 1998, n 52 above p 531. 
achieved, the resulting law will have to be implemented by the machinery of government within certain bounds set out in the legislation. This traditional view of constitutional law is "contingent upon the presence of a single administrative system which only it has the authority to recognise". ${ }^{57}$

In essence, it is argued that this type of analysis rests on the questionable assumption that in all areas the government and the state, operating under the constitution, have an exclusive and proactive role. More specifically, we will shortly see in regard to devolution that such a view fails to account for the way power is actually exercised in the modern state. Foucault wrote that:

"the analysis of power relations within a society cannot be reduced to the study of a series of institutions, not even to the study of all those institutions which would merit the name "political." Power relations are rooted in the system of social networks". 58

This has a particular resonance in a contemporary context which has seen numerous attempts to relate the performance of government to the human subject. Under these arrangements it is the individual's ability to reorganise and contest power in many different sites which becomes crucial and this recognises that there has been a profound disordering process. In turn, this is a situation that requires a new politics, more concerned with individual subjectivity as individuals become more pro-actively engaged in the management of their own government. ${ }^{59}$ Such a redistribution of power occurs "not so much from one process trumping the other but from the operational tension between the administrative mechanisms for shared rule and the administrative mechanisms for self-rule". Ultimately this process leads to an operational redistribution of administrative power. ${ }^{60}$

Further, we will see that it has become apparent that "governmentalization" as a process is at once both internal and external to the state. Thus the task of those governing is no longer merely about imposing sovereign will through legislation and becomes more about engaging with the many networks and alliances that make up a chain of networks which translates power from one locale to another. ${ }^{61}$ Moreover, as the monolithic state dissolves into these complex webs of relationships we find exposed and challenged any clear distinction between the public and private sphere. The issue at the micro-level becomes one of the exercises of the bio political technologies of power within a particular domain, be it public or private, and

57 D. Chalmers 'Post-Nationalism and the Quest for Constitutional Substitutes' Journal of Law and Society [2000] pp 178-217 at p 192 and see generally.

58 M. Foucault 'Afterword, The Subject and Power' in H. Dreyfuss and P. Rabinow Beyond Structuralism and Hermeneutics, (1982), p 224.

59 Chalmers [2000] n 57 above p 196.

${ }^{60}$ Ibid p 202.

61 J. Morison 'The Government-Voluntary Sector Compacts: Governance, Governmentality, and Civil Society' Journal of Law and Society, Vol 27, No.1 March 2000 pp 98-132 at p 122. Morison discusses Foucault's later work on "governmentalization" and considers how the proper subject of an analysis of contemporary forms of government should be those networks and alliances which exercise "government at a distance". See further M. Foucault 'Governmentality' in G.Burchell, C. Gordon and P. Miller The Foucault Effect: Studies in Governmentality, (1991). 
the task now is to investigate how this can be constructed from the base level of the human subject. ${ }^{62}$ For example in relation to public law, this investigation might include examining the emergence of compacts, the resort to soft law techniques such as concordats and a recognition of the importance of strategies of new public management.

This is not the place to further develop this discussion at a theoretical level but awareness of these considerations highlights the fact that the conventional constitution is increasingly unable to exercise its co-ordinatory function or to fulfil its role as a meaning-generating process. ${ }^{63}$ We will now proceed from this brief discussion of power in the modern state to attempt a more concrete level of engagement with some of these issues in relation to devolution. In particular, four areas will be considered: concordats, compacts, regulation and deregulation, and dealings with the European Union.

\section{(i) Concordats and Soft Law}

The first question is whether the implementational strategies adopted for devolution have had the effect of undermining some of its fundamental objectives. Devolution had to be somehow plumbed into the existing uncodified constitutional arrangements and it is no surprise that this has been proceeded with in an unsystematic fashion. In part, as we have already noted, this has been engineered by statutory provisions, but also it has been managed by mechanisms that exist and work outside the formal legislative framework. Intergovernmental relations call for a different and less formal process. Rather than the more familiar device in the UK of conventions, concordats and other less formal arrangements emerged fairly late in the process and "represent a further step down the road of juridification in the form of 'bureaucratic law's ${ }^{64}$ Thus for the picture to come into any sort of focus we find that, certainly at an administrative level, reference has to be made to a developing body of soft law.

It has been pointed out that "all complex, multi-level constitutional systems have had to develop tools to co-ordinate the exercise of powers distributed amongst various decision-making entities". ${ }^{65}$ Although the overall process in the UK has lacked any formal structuring there is a general Memorandum of Understanding (MOU) containing a set of principles. These include: good

62 Foucault's work has a distinctive conceptualisation of power which sees domination in the 'form of a combination or structure of knowledge and power which is not external to the subject, but still unintelligible from his or her perspective'. According to this view domination is not in any simple sense caused by subjects. See M. Poster Foucault, Marxism \& History, (1984) p 80.

63 Chalmers [2000] n 57 above at $\mathrm{p}$ 183-4.

64 See R. Rawlings 'Concordats of the Constitution' [2000] LQR 256-286 at p 258. This article presents an in depth critical evaluation of concordats. See also M. Laffin, A. Thomas and A. Webb 'Intergovernmental Relations After Devolution' Political Quarterly, [2000] 223-245.

65 J. Poirier 'The Functions of Intergovernmental Agreements: Post-Devolution Concordats in a Comparative Perspective' [2001] Public Law 134-157 at p 135 This is a comparative study which refers to the various roles of informal agreements in e.g., Canada, Australia, Germany and Belgium, as well as describing the part played by concordats in the UK devolution arrangements. 
communication and information-sharing, early warning of policy proposals, co-operation on matters of mutual interest and rules of confidentiality to be applied within the workings of the post-devolutionary system of government. ${ }^{66}$ The MOU is supported by a (still) increasing number of bilateral and multilateral agreements ${ }^{67}$ between the recently devolved executives and Whitehall departments which have been drawn up behind the scenes by senior departmental officials. ${ }^{68}$ The status of concordats varies markedly from inter-governmental agreements to more subject specific arrangements, with some set out in much greater detail than others. ${ }^{69}$ Further, the memorandum specifies that these are procedural rather than substantive agreements ${ }^{70}$ but nevertheless some contain significant substantive rules "indicat[ing] not only how things are to be done, but who must do them". For example, the Concordat on European Structural Funds specifies that responsibilities for implementation will be carried out by the Scottish executive and not the Scottish Office. ${ }^{71}$ The concordats have been referred to as "a form of codification of the processes of government" 72 and it is widely acknowledged that the concordats are of considerable practical importance for the administrative implementation of devolution. They have not only contributed significantly to continuity and smooth transition of policy but have also helped facilitate policy co-ordination between the many overlapping levels of modern governance. ${ }^{73}$

Certain aspects of these loosely drawn up arrangements are a cause of concern. First, the concordats have been introduced in a way that has contributed to a lack of openness and transparency and this in turn raises issues of political accountability. ${ }^{74}$ Despite the fact that the MOU and Concordats have been published and the information concerning their operation is placed in the public domain. ${ }^{75}$ The key point is that under the MOU the information exchange between the various players is made strictly subject to rules of confidentiality. Furthermore, the concordats fall under an

66 See Memorandum of Understanding and Supplementary Agreements, Cm 4806, July 2000.

67 See Poirier [2001] n 65 above p 146. Initially, there were 20 bilateral agreements between Westminster departments and Scottish Executive and five supplementary multilateral agreements between UK government, Scottish Ministers and Cabinet of the Welsh Assembly. The latest additions to the list are the Concordats between the DTLR (now office of Deputy Prime Minister) and the Scottish Executive and the DTLR the Northern Ireland Department of the Environment, published 27/2/02.

68 Some of the more sensitive Concordats have been signed by ministers (Poirier $\mathrm{n}$ 65 above $\mathrm{p} 148$ ).

69 Rawlings 2000 n 64 above p 263; Poirier 2001 n 65 above, p 135.

70 This emphasis on procedure is clear from the guidance notes: 'They will set down common processes and the main features of good working relationships, rather than specify substantive outcomes'. Guidance Notes on Common Working Arrangements: Annex A: Concordats.

71 Poirier [2001] n 65 above p 150.

72 Rawlings [2001] n 31 above at p 84.

73 Rawlings [2000] n 64 above p 276.

74 In much the same way as with other forms of quasi-contractual governance.

75 The concordats have been drawn up under a veil of civil service secrecy although later published. 
excluded category under the Freedom of Information Act $^{76}$ and this allows the routine meetings and dealings between officials that take place as part of these agreements to remain out of bounds. Thus a lack of transparency extends to a crucial aspect of the implementation of the entire process. The multifaceted inputs to the policy process are regarded as too sensitive to come under public scrutiny. Such an emphasis on confidentiality is hard to reconcile with New Labour's apparent commitment to openness and inclusiveness $^{77}$ but more seriously this conflicts with the wider task of scrutiny of the process of government resting with the parliamentary accountability mechanisms. ${ }^{78}$ For example, the continuing secrecy interferes with the effectiveness of the relevant subject committees forming part of the Scottish Parliament and Welsh and Northern Ireland Assemblies and obstructs the work of the departmental select committees for Scotland, Wales and Northern Ireland.

Turning secondly to legal controls, it will be remembered that it was explained in the introduction to this section that adherents to the functionalist view have always been resistant to dragging the law courts into the administrative process ${ }^{79}$ and it would appear at first glance that reliance on this form of soft law demonstrates the high value placed in the devolution arrangements on alternative or co-corporate forms of dispute resolution. ${ }^{80} \mathrm{~A}$ preference for non-contractually binding concordats relying on flexibility and co-operation as the main technique for resolving administrative problems has the advantage of keeping the judges in the civil courts at bay, but the difficulty is that the alternative procedures for routine dispute resolution are insufficiently open and participatory. The concordats are very wide ranging

76 Freedom of Information Act 2000, Part II Section 28 (1) 'Information is exempt information if its disclosure under this Act would, or would be likely to, prejudice relations between any administration in the United Kingdom and any other such administration'. It should be noted that the act will only fully come into force in 2005.

77 Rawlings 2000 n 49 above p 279. See Modernising Government (Cm 4310 1999). In contrast to other examples such as the decision to release the minutes of the meetings of the Monetary Policy committee of the Bank of England.

78 It is worth noting on this point that the Scottish legislation on freedom of information is more robust in comparison with England and has included a 'substantial prejudice' test for excluding information from release into the public domain. See Freedom of Information (Scotland) Act 2002 ss 27 and 28 and P. Birkinshaw Freedom of Information, 3rd ed (2001) at $\mathrm{p} 327$.

79 See M. Loughlin Public Law and Political Theory, (1992) p 168ff "In general public law should ensure that the legal framework within which government operated provided an effective and equitable structure for the implementation of the public good, as expressed in the positive functions of the state". This approach 'also stressed the need for a rational system of administration' and regarded the courts as 'ill-equipped for this task'. Further, there has been a familiar critique of the 'political' nature of decisions taken by unrepresentative judges. See e.g. Griffith JAG The Politics of the Judiciary, $5^{\text {th }}$ ed (1997) at $\mathrm{p} 336$.

${ }^{80}$ In this can be identified certain affinities between the principle of federal comity/loyalty and having concern for the interest of other orders of government which in encourages a spirit of co-operation. See e.g. Poirier $2001 \mathrm{n} 65$ above p 152 . 
and touch upon numerous areas of sensitivity and difficulty. ${ }^{81}$ And so it is surprising that elected representatives from the devolved legislatures have no role in the process at an early stage. At present any wider involvement depends upon reference of a dispute to the Joint Ministerial Committee. While recourse to private law has been limited, it would appear that in the current climate of judicial activism public law intervention remains a possibility. This would be the case if the failure to adhere to the terms of a concordat could be argued to fall under one or more of the grounds of judicial review. ${ }^{82}$

In addition, there are some important concerns which relate to the sense in which the network of concordats have been, in effect, used as a means of setting an unofficial seal on an existing bureaucratic culture centred upon the influence of Whitehall and the Cabinet Office. It has been suggested that in order to achieve "continuity in a changed constitutional landscape" there has been "a failure of constitutional vision, with the custom and practice of Whitehall being too often regenerated in the modalities of intergovernmental relations". ${ }^{83}$ There is strong evidence to suggest that these concordats have been formulated in a spirit that reinforces an unequal partnership that permits domination from the centre. This domination has been illustrated by reference to the operation of the Joint Ministerial Committee. At a political level not only do UK Ministers and departments represent the interests of England on all matters, but the task of chairing meetings is granted exclusively to UK ministers. At a bureaucratic level, the Cabinet Office is in a position of hegemony retaining a grip on the shaping of the arrangements as a whole. Another aspect of the undeclared agenda seems to be an interest in retaining a unified home civil service. ${ }^{84}$ This has obvious advantages in facilitating smooth transitional arrangements and in permitting mobility between administrations. The drawbacks are equally obvious. For as long as officialdom operates under established rules the existing Whitehall culture is likely to continue to prevail. ${ }^{85}$ The political implications are that these internal working are put outside of the reach of the democratic process, since the civil servants are placed in a position of being able to by-pass Parliament when operating under these arrangements. ${ }^{86}$

\section{(ii) Compacts and Governance}

At a sub-governmental level and one that is to some extent addressed by devolution we can see how the idea of "compacts" have developed. These amount to a collaboration between government and parts of the voluntary

81 The relationship between the devolved executives and the EU discussed below is a good example of this.

82 See Rawlings $2000 \mathrm{n} 64$ above at p 283. For example, should there be a failure to consult, or if they give rise to a procedural legitimate expectation.

83 Ibid p 276, p 261 and p 278.

84 Although Northern Ireland has a devolved civil service.

85 Rawlings 2000 n 64 above p 270 and 278; Piorier above n 65 at p 154.

86 In some cases the concordats fall outside the remit of Westminster departmental select committees. Michael Ancram was highly critical in Parliament of the tendency to undermine Parliamentary Sovereignty and popular sovereignty by bypassing Parliament through the use of concordats. This criticism was further elaborated Ancram M 'The Dictatorship of the Concordat' The Times, March 4, 1998. 
sector and also partnerships between the business sector, government and the voluntary sector. A theme here is of the voluntary sector mediating between the state and the market. ${ }^{87}$ Such arrangements are becoming more prevalent and represent one example of how power is actually exercised in and beyond the modern state. ${ }^{88}$ They not only demonstrate that power is dispersed throughout society, but also that the formal limits between civil society and state are in reality traversed by networks which operate across constitutional boundaries. ${ }^{89}$ This tendency can be identified in a new language which finds its way through a process of negotiation into codes of practice. Thus it has been claimed that ". . . the compact process provides a mechanism for facilitating the translation between the moralities, epistemologies, and idioms of political power of the two broad groups, and the further development of the relationship".90 It might then be concluded that government perhaps in pursuit of a "third way", is seeking to operationalise "a particular, ultimately managerially driven programme by influencing, allying with, and co-opting the voluntary sector as a resource that they do not directly control". ${ }^{91}$ The compacts share certain common features and there have been attempts towards achieving best practice and establishing accounting mechanisms to secure the most efficient use of resources. But if, as seems likely, these compacts become increasingly important in the delivery of policy the fact that they are locally negotiated under different ground rules in each part of the United Kingdom is likely to further emphasise the diverse and asymmetrical effects of the devolution arrangements. ${ }^{92}$

\section{(iii) Regulation and Deregulation}

The next area concerns regulation of the public private sector monopolies and utilities and deregulation as it effects the business sector more generally. Regulation is a matter that the devolution legislation itself hardly touches upon directly. ${ }^{93}$ This means that the changes in administration have not been

87 Modernising Government (Cm 4310 1999); Getting it Right Together: Compact on Relations between Government and the Voluntary Sector and Community Sector in England (1998: Cm 4100); The Scottish Compact: The Principles Underpinning the relationship between Government and the Voluntary Sector in Scotland (1998; Cm 4083); Building Real Partnership: Compact Between Government and the Voluntary Sector in Northern Ireland (1998: Cm 4167)

88 See: s 114 Government of Wales Act 1998 which states that the Assembly must set out how it proposes in exercising its functions, to promote the interests of relevant voluntary sector organisations; s 56 of the Northern Ireland Act which requires the First Minister and Deputy First Minister to consult the views of the Northern Ireland civic forum (consisting of representatives of business, trade unions and the voluntary sectors) on social economic and cultural matters. The compacts do not specifically feature as part of the Scotland Act but codes of good practice have been drawn up by the Scottish executive in conjunction with leading voluntary sector bodies.

89 J. Morison 'The Government Voluntary Sector Compacts: Governance, Governmentality, and Civil Society', Journal of Law and Society, 2000, 98-132 at p 124.

90 Ibid $\mathrm{p} 127$.

91 Ibid $\mathrm{p} 131$.

92 Ibid $\mathrm{p} 114-117$ and $\mathrm{p} 130$.

93 See the Scotland Act 1998 Sch 5 which lists energy and transport under reserved matters. For an up to date overview of regulation see T. Prosser 'Regulation, 
linked to any discernible strategy for the containment of functions and powers that are exercised across borders and within the UK. ${ }^{94}$ In the realm of transport, energy and the utilities an intersection of power relationships takes place at both a sub and supra national level. Furthermore, it is widely recognised that the need for regulation has not declined post privatization ${ }^{95}$ and that accountability ${ }^{96}$ under current conditions of governance has to be related to the effectiveness of regulation which has been one of the chief instruments of government for the achievement of important policy objectives. $^{97}$ To this end, there has been a proliferation of new forms of secondary regulation by government of privatised industry outside of Parliament and the courts which has become "more formal, complex and specialised". By the mid 1990's in the UK there were 135 regulatory bodies costing $£ 770$ million. $^{98}$ Of course, regulation continued with the Labour government ${ }^{99}$ but although there has been an emphasis increasingly on coordination the devolution arrangements fail to adequately address the issue of cross border regulation. ${ }^{100}$

Although space precludes any detailed discussion here, the regulation of the public utilities of water, gas and electricity demonstrates the added complexity of the regulatory task since devolution. There are significant

Markets and Legitimacy' in J. Jowell and D. Oliver The Changing Constitution, $4^{\text {th }}$ ed, (2000).

94 For topical in depth discussion of the issue of accountability and regulation see e.g., G. Majone 'The Regulatory State and Its Legitimacy Problems' Western European Politics, Vol 22, No.1, January 1999 pp 1-24; Scott C 'Accountability in the Regulatory State' Journal of Law and Society, Vol 27 No 1, March 2000, pp 38-60 particularly at $\mathrm{p} 48 \mathrm{ff}$.

95 The failure to set in place regulation following bus privatisation has meant an unchecked decline in standard and frequency of service delivery and in safety. See W. Hutton The State to Come, London, Verso, 1997 p 20. However, note that Part I of the Transport (Scotland) Act 2001 introduces a new regime of regulation for bus services in Scotland.

96 Accountability in this context can be broadly defined as 'an obligation for a person or organisation to justify actions to another body in terms of some authorisation for the activity given by that body including assignment of duties or purposes, answerability, overseeing performance - incentives for good performance and penalties for inadequate performance. See O. James 'Regulation Inside Government: Public Interest Justifications and Regulatory Failures' [2000] Public Administration 327-343 at $\mathrm{p} 328$.

97 C. Harlow C \& R. Rawlings Law and Administration, $2^{\text {nd }}$ ed. (1997) p 295.

98 C. Hood, O. James, and C. Scott 'Regulation of Government: Has it Increased, Is it Increasing, Should it be Diminished' [2000] Public Administration 283-304 at p 285. See also A. Midwinter and N. Garvey 'In Search of the Regulatory State: Evidence from Scotland' Public Administration Vol 79 No 4, 2001 825-849 for a discussion of regulation inside government rather than economic regulation.

99 The reform the Post Office is the latest example of this. See Post Office Reform: A World Class Service for the $21^{\text {st }}$ Century, $1999 \mathrm{Cm} 4340$ and The Postal Services Act 2000. Postcomm, the industry regulator under the Postal Services Act, published its decision on the introduction of competition for the UK postal market on 29 May 2002. See also T. 'Prosser Regulating Public Enterprises' Public Law [2001] 505-527 at p 506ff.

100 Modernising Government (White Paper) Cm 4310, 1999. Regulation continues as a priority in latest UK government thinking with an emphasis upon comparing the performance of public bodies against 'quality' systems in the private sector. 
differences in local conditions of ownership and operation of these industries to those prevailing in England. This is partly as a result of there being less privatisation in Scotland, Wales and Northern Ireland but the situation has been compounded by devolution. First, this is because legislative competence to regulate has been devolved for some industries while in others a UK regime of regulation remains in place. ${ }^{101}$ Second, this is because of the engagement of different layers of regulation. For example, the utility sector necessarily involves the overlapping and integrally related question of environmental policy and economic regulation. It is important to note that only responsibility for environmental regulation has been devolved. ${ }^{102}$ The obvious point is that this added complexity presents new challenges for coordination of regulatory agencies across both territorial and policy boundaries.

If we take another high profile area, namely, the regulation of the performance of the rail industry and particularly of Railtrack post privatisation. This has called attention to the inadequacy of the original regime of rail regulation and it is clear from a functionalist standpoint that legislative solutions were required in this field. In fact, under the Transport Act 2000 the government decided to improve the regulatory framework by increasing the powers of the regulators and by establishing a Strategic Rail Authority (SRA) which amounts to an additional layer of regulation. ${ }^{103}$ This path was preferred to fully or partially returning Railtrack to public ownership. Transport is a policy area that has been partly devolved ${ }^{104}$ and it is important to note that the Transport Act 2000 makes overtures towards recognising the interests of Scotland and Wales by specifying that membership of the SRA must include a person nominated by a Scottish Minister and the Welsh Assembly, and it provides that in formulating strategies Scottish Ministers and the Welsh Assembly must be consulted ${ }^{105}$. Further, Section 208 (1)(a) provides that Scottish ministers can provide the Strategic Rail Authority with directions and guidance in respect to services under a franchise agreement that end in Scotland. However, the remit of the Office of Rail Regulation (ORR) whose principal function as an independent regulator was to oversee Railtrack's stewardship of the national rail network has not been significantly modified to take account of devolution. The

101 Contrast the economic regulation of the Water industry in Scotland which is devolved with gas and electricity which is not.

102 See C. Graham Regulating Public Utilities: A Constitutional Approach, (2000), chapter 6; P. Leyland 'UK Utility Regulation in an Age of Governance' in N. Bamforth and P. Leyland (eds) Public Law in a Multi-Layered Constitution, Oxford, Hart Publishing, forthcoming 2003.

103 The Strategic Rail Authority officially commenced operation in February 2001 and it is under a duty to promote and develop the rail network and promote integration. Also, through the re-negotiation of the next round of rail franchises the SRA will be able to have a role in regulating fares.

104 Scotland has a minister for Transport and Planning, Wales a minister for the Environment which includes transport and Northern Ireland a Minister for Environment (with only a limited transport brief).

105 See Transport Act 2000 s 202 and s 206. A 'Stakeholder Relations Manager' (Mike Connelly) for the Strategic Rail Authority was appointed in June 2002 and has been given responsibility for 'the effective delivery of train services in Scotland'. 
changes fall short of tailoring rail regulation to the special needs of Scotland and Wales. ${ }^{106}$ Most notably, there has been a continued reliance on Railtrack for investment in the infrastructure of the system and since the role of the ORR and now the SRA have not been directly related to the aspirations of the devolved governments their own published objectives will be difficult to achieve. ${ }^{107}$ The Scottish Executive in issuing its Directions and Guidance in 2002 for new franchises that will operate from 2004 has set out its broad objectives for an improved rail network in Scotland, including tougher conditions on franchises and projected new lines but any such plans will be heavily dependent on the level of investment that is available following the collapse of Railtrack in 2001 and its replacement in 2002 by a not-for-profit company called Network Rail. ${ }^{108}$

Deregulation is an issue which has been very much on the agenda of the Scottish Executive as well as the Westminster government. ${ }^{109}$ The amount of red tape and the level of business rates have been perceived as a matter of prime concern especially for small businesses. The Scottish executive is committed to decisive action calling on the forces of 'joined up' government with the involvement of several departments to tackle the problem. It has recognised that in order for Scotland to become more attractive to investors decisive action must be taken in this field. To this end, the Enterprise and Lifelong Leaning department of the Scottish Executive have established a unit called "Improving regulation in Scotland", referred to as IRIS. ${ }^{110}$ The better regulation strategy has been presented as a ground breaking departure from previous practice and has a number of notable features. For example, all Scottish regulation which impacts significantly upon business will now be subjected to a "regulatory MOT" within 10 years to ensure that each regulation remains fit for purpose; a micro business test will be employed to assess the possible impact of any regulation on businesses employing up to 5 people; a new requirement that any proposal for additional regulation must

106 The Transport Act 2000 s 249(1) require the Scottish Ministers and the Welsh Assembly to be informed about any scheme for improvement and development while 249(2) Allows Scottish Ministers and the Welsh Assembly to enter agreements for improvement or development of services for the carriage of goods.

107 Such goals are set out in: Travel Choices for Scotland: The Scottish Integrated Transport White Paper, (Cm 40 July 1998): Following a rail audit conducted in November 1999 The Assembly Vision for Rail Services in Wales and the Borders: A Guide for Franchise Bidders looks forward to a coherent network of rail services as part of a coherent transport network and considers route strategies and service levels.

108 Scottish Executive press release 12/06/02 'Executive Outlines Scottish Rail Plans'. For example, T. Bolden and R. Harman 'Realising the New Opportunity for Railways' Public Money and Management April-June 2002 61-66 at 63 point out that the the SRA's strategic plan leaves unanswered the crucial question of how the investment capital needed will be raised. A court order allowing Railtrack to be taken out of administration was issued on 2 October 2002.

109 See the Concordat between the Cabinet of the National Assembly of Wales and the Department of Trade and Industry, December 1999, Annex D deals with cost sharing for regulatory impact appraisals of legislation.

110 There has been a similar initiative in England with the Cabinet Office Regulatory Impact Unit, the Better Regulation Task force and the provisions of the Regulatory Reform Act 2001. 
by accompanied by a regulatory impact assessment to consider whether it is really necessary; there will be regulatory summits bringing together regulators and regulated; and there will be test runs for business forms before they are introduced. ${ }^{111}$ One issue is whether such developments will lead to problems in synchronising policy in this area with other parts of the United Kingdom. ${ }^{12}$ It should be remembered that although deregulation may benefit commercial interests controls may often be essential in the wider public interest and it has been recognised that the consequences of removing regulation or inadequate regulation can have a devastating impact. ${ }^{113}$ Thus any deregulation strategy needs to establish a balance between such considerations and be co-ordinated throughout the UK. ${ }^{114}$

\section{(iv) Dealing with Europe}

This final section considers the sensitive question of how the measures themselves attempt to reconcile the interests of the UK and the devolved nations in regard to the EU. This is likely to be a matter of steadily increasing importance and failure on this front may lead to increasing instability. For example, nationalists (particularly in Scotland) regard the present settlement as simply a staging post prior to outright independence and argue that Scotland would be better off as an independent state within the European Union. The Irish Republic serves as one obvious model ${ }^{115}$ and on Scotland's doorstep are several small independent nation states benefiting from their status in the European Union (Belgium, Holland, Luxembourg, Denmark). Whatever the merits of the more general case for independence, an obvious shortcoming is that the UK devolution project fails to adequately address the complexity of the European issue. ${ }^{116}$ This is especially problematic because Brussels legislates in the same fields to those over

111 Press release entitled 'Ground breaking package to boost small business' launched by Henry McLeish, the then Scottish First Minister, 15 ${ }^{\text {th }}$ February 2001. This is linked to the IRIS initiative (improving regulation in Scotland). Guidelines have been set out in a Scottish Executive publication entitled 'Good Policy Making: A Guide to Regulatory Impact Assessment'.

112 The Concordat between the Cabinet Office and the Scottish Administration has a paragraph (24) on regulatory impact which merely states the need to work together to identify good regulatory practice.

113 See The BSE Inquiry Report: http://www.bseinquiry.gov.uk/report which links the emergence of new variant CJD to changes in farming practices. This was allowed by a relaxation in the ban on ruminant cattle feed.

114 It is important to recognise that there has been a parallel initiative towards deregulation in England. The Deregulation and Contracting Out Act 1994 and now the Regulatory Reform Act 2001 gives ministers powers to reduce the burden of regulation on industry and the Public Sector Team operating from the Cabinet Office is aimed at reducing public sector bureaucracy and red tape. The work of this team has been concentrated on certain specified policy areas e.g. health, police forces, schools and local government.

115 Although Scotland's relationship with Europe may be a significant aspect in any case for full independence, it should be recognised that re-negotiated economic arrangements between England and Scotland would be of crucial importance too.

116 See G. Clark 'Scottish Devolution and the European Union', [1999] PL 504 who at p 508 stresses the importance of gaining influence at the Council of Ministers and points out that Scottish Office ministers would attend meetings of the Council of Ministers with the agreement of the "lead" department. 
which power has been devolved, ${ }^{117}$ for example, economic development, agriculture and fisheries, the environment, training and enterprise.

In Scotland and Northern Ireland the implementation of community law within the jurisdiction is made a matter for the devolved executives. ${ }^{118}$ However, the legislation is bewilderingly complex by also establishing a concurrent power for the implementation of European law. The legislation further provides that where Scottish/Northern Irish Ministers are empowered to use section 2(2) of the European Communities Act 1972 to implement obligations under Community law, a Minister of the Crown also retains power to use section 2(2) for the same purpose. This introduces an element of ambiguity concerning compliance with EU law. This can be resolved by reference to the Concordat on Co-ordination of European Union Policy Issues. The UK government is ultimately responsible for ensuring that community law is enforced and thus the provisions in the legislation and the Concordat as the preferred mechanism for co-ordination emphasises financial penalties which will apply to a devolved administration for failing to act on time. This approach can be contrasted with the situation in Germany where the Federal Government is prevented from interfering where the issue comes under the remit of a Länder. ${ }^{119}$ A strong case can be made for modifying the devolution legislation to clarify this position by removing these overlapping powers and placing responsibility for implementation of EU law on the devolved administrations.

On the other hand, responsibility for dealing with the EU is a reserved area for Westminster. ${ }^{120}$ This means that Scotland, Wales and Northern Ireland's role in Europe at the Council of Ministers is negotiated and represented by British and not by ministers from the devolved executives. ${ }^{121}$ The legislation confirms a division of power that reflects the basic constitutional position of the UK and all other nations that are members of the Europe Union. It is member states that are responsible for forming agreements on policy matters and this requires them to reach a common negotiating position in advance. ${ }^{122}$ We have already observed that engagement with Europe has not been overlooked by devolution. At an executive level there is provision for involvement of the devolved nations through the Concordat on Co-ordination

117 Members of the European Parliament are now elected by PR and this allows the full range of political parties to be represented at a European level (e.g., there are two Scottish Nationalist members) but the European Parliament only has limited powers over legislation.

118 Scotland Act 1998 s 57 and Northern Ireland Act 1998 s 6(2)(d).

119 A. Cygan 'Scotland's Parliament and European Affairs: some lessons from Germany, 1999 European Law Review 483-499 at p 495.

120 See Scotland Act 1998 Schedule 5 (7). See also V. Bogdanor 1999 op cit n 8 above $\mathrm{p} 276 \mathrm{ff}$ who explains the constitutional implications in regard to Europe.

121 The Concordat on Co-ordination of European Union Policy Issues is the preferred pseudo-contractual mechanism for dealing with European affairs. See Rawlings [2000] n 64 above at p 272-274. It is pointed out that the ground rules have been drawn up to favour a 'UK team' approach with composition determined by the UK minister.

122 The Treaty of Nice 2000 looks forward to a greatly expanded European Union in which the voting rights of individual nations will be adjusted and where qualified majority voting is extended to more areas, but there is no suggestion of allowing national votes to be split. 
of European Policy Issues. This is an important move towards allowing genuine consultation with an emphasis on working as a team but an obvious problem arises when English interests strongly diverge from those of Scotland, Wales or Northern Ireland thus making agreement on a matter impossible. Where any such disputes cannot be resolved, the English position is likely to predominate and the votes for the UK at the Council will then by cast in accordance with the UK position. This process has been regarded as unsatisfactory by representatives of devolved nations throughout Europe. In response to pressure from the German Länder it is well known that European Union rules were amended by Article 203 (formerly 146) Treaty of the European Union. The revised arrangement allows representation at a sub-national level on the Council of Ministers ${ }^{123}$ but there seems little immediate prospect of the UK following this example. ${ }^{124}$ Furthermore, at an operational level there has been no real attempt to ensure that the interests of the devolved nations are represented on the world stage. ${ }^{125}$

Turning more specifically to Scotland, we find that there has been progress in promoting Scotland's cause in Europe. First, it is highly significant that the Scottish executive set up an EU office in Brussels in 1999 to further Scotland's interests. ${ }^{126}$ The office aims to achieve this by providing the executive with operational support, by information gathering, by assisting and influencing policy and by raising the profile of Scotland in the EU. It reports directly to the Head of the Scottish Executive secretariat. ${ }^{127}$ Second, the executive has been given responsibility for implementing programmes for European structural funds as the managing authority. These were previously administered by the Scottish Office. ${ }^{128}$ The structural fund is the second largest item of European expenditure which is directed at correcting disparities between the European regions and it is expected that the next round will result in more than $£ 1$ billion of European money finding its way

123 In contrast, the German Federal system provides constitutional safeguards under Article 23 to insure involvement and representation, but this is only a limited gesture which provides a voice to sub-national interests. Under current arrangements the voting power still remains with the German Federal Government. See Cygan [1999] n 119 above at p 489.

124 This anomaly was again pointed out by Roseanne Cunningham of the SNP in a recent debate in the Scottish Parliament with reference to the Scottish fishing industry. There is currently no Scottish ministerial representation in Europe for this very substantial industry which employs up to 26,000 people in Scotland. It was pointed out by her that Belgium which also has fishing mainly in the Flemish part of the country will have a Flemish minister to represent Belgium on European Fisheries councils from 2002. Scottish Parliament, European Debate, $9^{\text {th }}$ May 2001, Vol 3, No 72.

125 Scottish interests in regard to the exploitation of North Sea oil is an area where such representation could be important.

126 For analysis of the main thrust of Scottish Executive involvement in Europe at number of different levels (Council of Ministers, Commission, Committee of the Regions) see A. Sloat 'Reconfiguring Scottish Politics: Domestic Governance vs European Influence' in this issue at pp 435.

127 R. Hazell R and D. Sinclair 'The British Constitution in 1997-98' [1999] Parliamentary Affairs 161 at p 164.

128 See the Concordat on European Structural Funds, art.12. Poirier 2001 n 65 above p 150. 
to Scotland. ${ }^{129}$ Third, the Scottish Parliament takes an active part in Europe through its European Committee which is responsible for scrutinising documents and proposals emanating from Brussels. This includes a process of continuous review on the manner in which the executive manages the structural fund. ${ }^{130}$ The European Committee has a general role in developing the Parliament's approach to EU matters. ${ }^{131}$ Europe has a wide impact on the work of the Scottish Parliament and it has been suggested that other committees should be able to develop the European aspects of matters within their remits. ${ }^{132}$

\section{CONCLUSION}

At this point it is worth considering whether the devolution initiative is capable of addressing the pressing contemporary problems facing the nation state which is on the defensive against a world economy it appears unable or unwilling to control. ${ }^{133}$ It has been argued that wider globalising tendencies mean that,

“. . . the locus of effective political power can no longer be assumed to be national governments - effective power is shared, bartered and struggled over by diverse forces and agencies at national, regional and global levels ... political power is being repositioned, recontextualized and, to a degree transformed by the growing importance of other less territorially based power systems". ${ }^{134}$

Although this battery of devolution legislation can be regarded as a significant stride towards a written constitution for the United Kingdom ${ }^{135}$ the key question is whether there is a general fitness for purpose, whether these new forms of constitutionalism proposed as an alternative way forward are based upon an understanding of the different levels at which power now operates. Chalmers maintains that constitutions or constitutional substitutes will continue to perform a role in subjecting all political and legal action within this context to processes of co-ordination, assimilation, recognition and rational self-critique. This is task which is achieved through strong steering mechanisms ${ }^{136}$ and a "pluralisation of regulatory authority". While

129 The situation in Wales in regard to Europe is in some respects similar. The Assembly has an office in Brussels and a standing committee on European Affairs to ensure that the Assembly takes a coherent strategic approach to Europe and support the subject committees. The Welsh European Funding Office was set up as an executive agency by the Assembly in July 2000. From April 2001 the Office took over responsibility for administering the European Social Fund in Wales.

130 European Committee $1^{\text {st }}$ Report 2001, SP paper 259.

131 The remit of Scottish Parliament's European Committee is to consider and report on: (a) proposals for European Communities legislation, (b) the implementation of European Communities legislation, (c) any European Communities or European Union Issue.

132 Scottish Parliament press release $19^{\text {th }}$ February 2001; Burrows [2000] n 53 above at $\mathrm{p} 132 \mathrm{ff}$.

133 E. Hobsbawn Age of Extremes: The Short Twentieth Century, (1995) p 576.

134 D. Held et al Global Transformations, (1999) at p 447.

135 Rawlings [2001] n 31 above p 90.

136 Chalmers [2000] n 57 above at p 206 
for Morison the revised constitutionalism will enable 'radical communicative and participatory ideas of democracy' to challenge the limits of traditional liberal individualistic democracy' and it is suggested that a new technology of constitutional control is required 'to capture fugitive power'. ${ }^{137}$ This will also achieve "more and better democratic deliberation". In time we must come to rely on a concept of "participatory or dialogic democracy" which calls for "the public sphere [to] be rendered genuinely public as a place where discourse opinion forming and, indeed, decision taking can take place on a basis of real equality and participation. .." ${ }^{138}$

Such proposals may have some appeal as a general objective and there are aspects here that mirror the language of a New Labour discussion document but the practical implications are hardly a substitute for conventional constitutional and legal norms. It must be remembered that this discussion takes place against a background of growing voter apathy throughout the United Kingdom. In fact, this kind of approach mainly boils down to "more imaginative ways of assessing [voter] preferences" (citizen juries, surveys, preferenda, consensus conferences and focus groups are among the options mentioned) and more to the point for us here, there is a lack of any practical alternative proposals for reformulating and restructuring the intermediate stratas of governance that have been the main concern of this article. Something that can best be achieved by improved legislative initiatives. Lastly, on this point, it is worth remembering that, in theory at least, the New Labour project to renew social democracy is based on a new democratic state "recast on an active and participatory basis" where there is "no authority without democracy". ${ }^{139}$ To some extent we have already noted that participation, consultation and openness are features of the devolution measures that have been introduced. ${ }^{140}$ But how far does this accountability extend given that no direct relationship between the power to raise revenue and the power to spend it is included in the new arrangements? With the rather marginal exception of Scottish tax raising powers devolution fails to address the central requirement of democratic control. ${ }^{141}$

We have observed in the discussion of concordats, compacts and regulation that the kind of bottom up approach which examines the exercise of power in the modern state from the perspective of the human subject reveals the complexity of policy networks and shows that these cut across any previous public private distinction. In another sense, the European principle of subsidiarity suggests that policy implementation should, where possible, take place at the most local level. Indeed, as we have just noted, it seems to be fashionable in political and academic circles to propose that a solution lies in moving power closer to the citizen by further dividing up the delivery of

137 Morison, [1998] n 52 above at p 533.

138 Ibid $\mathrm{p} 532$

139 A. Giddens The Third Way, (1998) at p 66. Morison, [2000] n 52 above p 113 considers Labours 'Compacts' which in Scotland, Wales, Northern Ireland and England seek to build a new relationship between government and the voluntary sector 'as genuinely baffling documents . . . made up mainly of warm words, platitudes and generalities'.

140 See e.g. SA, GWA, Part VII Northern Ireland Act.

141 J. McEldowney 'The Control of Public Expenditure' in J. Jowell \& D. Oliver The Changing Constitution, $4^{\text {th }}$ ed (2000) at $\mathrm{p} 212$. 
policy and by encouraging consultation, democratic participation and placing greater emphasis on individual rights. ${ }^{142}$ But can such vaguely conceived initiatives really offer a viable way forward? It is pretty evident that policy networks which were already protracted and complex have become even more so with devolution. Thus a major problem is fragmentation of the administrative structure. At the same time it is very apparent that we have devolution which is secured by convention and political agreement and not by "... legally binding and justiciable constitutional norms. What is missing is a constitutional principle to bind the devolution settlement together and provide a legal guarantee of devolved autonomy". ${ }^{143}$ The main formal device which has been put in place to co-ordinate central regional relations is the Joint Ministerial Committee (JMC) which meets annually in plenary session and includes the PM, deputy PM and the first ministers of Scotland, Wales and Northern Ireland. But it appears that given the asymmetrical basis of devolution this is unlikely to evolve into a multilateral mechanism on the Austrian model and will be mainly concerned with the limited number of disputes that cannot be resolved bilaterally. ${ }^{144}$

Devolution has been regarded as an irrevocable constitutional departure. Following approval by referenda the legislation has set in place a fresh governmental structure, with a mainly new line up of politicians and leaders elected to perform specified roles and the administrative framework has been re-organised. Yet within the first two years the Westminster government has suspended the Northern Ireland assembly on several occasions and power has been returned to the Northern Ireland Office. ${ }^{145}$ Despite this, the administration in Northern Ireland continued to implement policy without the contribution of the assembly and the power sharing government. Civil

142 Jack Straw, the British Foreign Secretary has recently called for the introduction of a European Constitution in a speech to the Edinburgh Chamber of Commerce, August 27 2002. His first proposal recognises the need to enforce the principle of subsidiarity on a community wide basis to ensure that decision making takes place at a local level. This would involve a new type of enforcement mechanism or watchdog to be created. His second proposal recognises the need for a codification of principles: 'a case for a constitution which enshrines a simple set of principles, sets out in plain language what the EU is for and how it can add value, and reassures the public that national governments will remain the primary source of political legitimacy. This would not only improve the EU's capacity to act; it would help to reconnect European voters with the institutions which act in their name'.

143 Burrows 2000, n 53 above at p 120.

144 M. Laffin, A. Thomas and A. Webb 'Intergovernmental Relations After Devolution' [2000] Political Quarterly, [2000] 223-245. At p 228 it is pointed out that these arrangements allow for further functional meetings of ministers in particular policy areas to sort out specific problems.

145 See Northern Ireland Act 2000 and devolved government was restored in May 2000. A new Memorandum of Understanding CM 4806 was published to coincide with this. Once again, the Secretary of State, John Reid decided to suspend the NI Assembly on the $9^{\text {th }}$ August 2001 faced with a break down of negotiations. See e.g., Patrick Wintour 'What the on-off Assembly means for Ulster ' and Comment, The Guardian 10 $10^{\text {th }}$ August 2001. The Assembly was again suspended in October 2002. Despite Loughlin's remarks (see n 12 above) about a reversal of the measures being inconceivable without a referendum, this is precisely what has twice taken place in Ulster. 
servants and the full range of other institutional mechanisms at all other levels continued with the processes of government, where necessary, taking their cue from the Northern Ireland Office. It is true that Northern Ireland has exceptional political problems but this capacity to virtually carry on regardless suggests that the new democratic institutions remain in an important sense peripheral to the exercise of power and to the administrative process itself.

Finally, it is remarkable that there has been no co-ordinated plan lying behind recent constitutional reform as it is clear that devolution, together with the Human Rights Act, House of Lords reform and freedom of information legislation are shaking the foundations of the informal constitutional arrangements that have been relied upon for many generations. This is a cause for concern not because these areas ought to be regarded as out of bounds for reform but because change opens the way for further change and with the UK constitution there is no braking mechanism. At this stage it might seem logical to propose that the situation requires the stabilising influence of a codified constitution which also tackles devolution from the perspective of the UK as a whole and gives comparable powers to the English regions. However, while revised constitutional measures through devolving power might provide an appropriate channel for policy initiatives to be developed at a more local level, it is evident that constitutional reforms have limitations. This is especially true when it comes to resolving questions of resource allocation and tackling the deep seated problems in many high profile areas of policy that apply to the United Kingdom as a whole. ${ }^{146}$

146 See e.g., W. Hutton The State We're In, (1996) and W. Hutton The World We're In, (2002) p 358ff. 